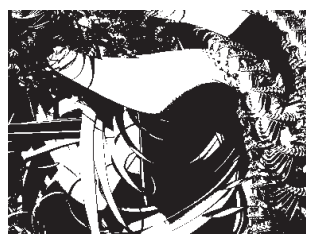

\title{
SUVREMENO SEBSTVO IZ KONTEKSTUALNE PERSPEKTIVE
}

Iva PASKA

Zagreb

UDK: 159.923:159.964.2

Prethodno priopćenje

Primljeno: 1. 7. 2009.

Namjera je ovoga rada upozoriti na ukorijenjenost sebstva u kontekstu njegove formacije i egzistencije. Rad se temelji na nalazima intersubjektivne psihoanalize, koja smatra da se sebstvo formira i kasnije egzistira unutar određenih ljudskih intersubjektivnih sistema. S obzirom na to da oni na taj način utječu na organizaciju sebstva, promatranje sebstva kao izoliranog ili transhistorijskog entiteta problematično je. Istodobno, intersubjektivni sistemi nužno su ukorijenjeni u širem kulturalnom sistemu, što vjedno znači da se i sebstvo formira i postoji unutar specifičnoga kulturnog konteksta koji utječe na njegovu organizaciju. To se u radu pokazuje na primjeru suvremenoga sebstva, čiji su se specifični problemi počeli zamjećivati u kliničkoi praksi 1960-ih godina. Zajedničkim nazivom najbolje ih se može okarakterizirati kao "tendenciju fragmentaciji", fenomen koji je primijetio psihoanalitičar Heinz Kohut. Taj se fenomen $u$ ovom radu povezuje s kontekstom formacije i egzistencije sebstva u suvremenom društvu. Tako je glavni cili rada na inovativan način povezati suvremene kliničke nalaze sa sociološkim kontekstom suvremenoga društva. Nastavljajući se na ovu teorijsku perspektivu, autorica nudi i vlastito sociopsihoanalitičko objašnjenje problema s kojima se susreće suvremeno sebstvo.

Ključne riječi: sebstvo, psihoanaliza, intersubjektivnost, modernost, kultura

E-mail: paska.iva@gmail.com

\section{UVOD}

U psihološkim perspektivama koje su se u zadnja dva stoljeća bavile sebstvom ono se uglavnom promatralo izolirano. Rijetko se promatralo u povezanosti sa kulturno-društvenim kontekstom unutar kojega nastaje i unutar kojeg egzistira. U para- 
DRUŠ. ISTRAŽ. ZAGREB GOD. 20 (2011) BR. 2 (112),

STR. $561-580$

PASKA, I.: SUVREMENO SEBSTVO... digmi klasične psihoanalize priznavao se, doduše, utjecaj okoline, no izvorom potencijalnih problema u daljnjem životu smatrao se u djetinjstvu oformljen intrapsihički konflikt između nagona i okoline. Psihoanalitičari koji su stavljali naglasak na kulturno, poput Karen Horney ili Jacquesa Lacana, u svojim su teorijama priznavali utjecaj okoline, no on se uglavnom fokusirao na utjecaj okoline $\mathrm{u}$ vrijeme formacije sebstva. U tom je kontekstu iznimka Harry Stack Sullivan, kao psihijatar koji je smatrao da je interpersonalni kontekst ključan u razumijevanju ne samo formacije nego i kasnijega funkcioniranja sebstva, te Alfred Lorenzer, koji je u svojim teorijama naglašavao ne samo potrebu za kontekstualnim nego i potrebu za interdisciplinarnim pristupom sebstvu, ali čije su teorije nakon 1970-ih godina izgubile na važnosti. Sebstvo u društvenom kontekstu bilo je i u žarištu skupine teoretičara koja se na području između društvenih znanosti i psihijatrije pojavila 1960-ih godina, povezivana s terminom "antipsihijatrija", prije svega Ronalda Davida Lainga, a onda još i Michaela Foucaulta i Ervinga Goffmana. No radovi tih teoretičara u današnjim su psihologijskim i psihijatrijskim praksama marginalizirani. Odnos sebstva i okoline bio je i predmet proučavanja mnogih teoretičara s područja društvenih znanosti i filozofije, no njihovi zaključci imali su malo doticaja s kliničkom praksom. Psihologijske su pak perspektive sebstvo uglavnom promatrale akontekstualno, kao neku vrstu "transhistorijskog entiteta" (Cushman, 1990.).

U drugoj polovici 20. st. sve češća pojava specifične organizacije sebstva koja se počela zamjećivati u kliničkoj praksi navela je neke psihoanalitičare da organizaciju sebstva i njegove simptome povežu s kontekstom unutar kojeg se sebstvo formiralo (Kohut, 1990.) te kontekstom u kojemu ono egzistira u trenutku pojave simptoma (Stolorow i Atwood, 2002.). Oni su došli i do zaključka da kontekst ne samo da je ključan za period formacije sebstva (Kohut, 1990.) nego da su simptomi sebstva povezani i s manjkavim kontekstom kasnije egzistencije (Stolorow i Atwood, 2002.). Iz toga slijedi da je perspektiva koja sebstvo promatra kao izolirani entitet nepotpuna i vodi do manjkava razumijevanja poteškoća s kojima se ono susreće. Navedeno se najbolje može pokazati na primjeru suvremene organizacije sebstva i društvenoga konteksta. Namjera je ovoga rada pokazati da se klinički psihoanalitički nalazi o suvremenom pojedincu mogu bolje razumjeti ako se povežu s makrosociološkim kontekstom suvremenoga društva. Takva se perspektiva promatranja sebstva u ovom radu naziva kontekstualnom te se pokušava upozoriti na njezinu nužnost i u kliničkim pristupima. 


\section{PROBLEMATIKA AKONTEKSTUALNOGA POGLEDA NA SEBSTVO I KONTEKSTUALNE TEORIJE}

Psiholog Phillip Cushman jedan je od teoretičara koji je na kraju 20. st. analizirao problematiku akontekstualnoga promatranja sebstva u svojem radu pod nazivom "Zašto je sebstvo prazno" (Cushman, 1990.). Cushman smatra da je glavni problem akontekstualnoga pristupa začarani krug s kojim se susreće osoba koja radi s modernim sebstvom, primjerice psihoterapeut koji "mora tretirati psihološke probleme bez mogućnosti imenovanja njihovih povijesno-društvenih uzroka" (Cushman, 1990., 599). I na teorijskoj razini, ako se sebstvo promatra kao "transhistorijski entitet koji se ne preispituje", postoji velika mogućnost da se u konceptualizaciji sebstva mnoge njegove karakteristike olako pripišu navodnim "inherentnim" svojstvima sebstva, poput bioloških predispozicija, dok se njihovo objašnjenje istodobno vrlo lako može naći u okolinskim faktorima, koji su, u takvoj izoliranoj perspektivi, zanemareni. Ako se pozovemo na intersubjektivnu psihoanalizu koja smatra da je organizacija sebstva povezana s karakteristikama intersubjektivnoga sistema $\mathrm{u}$ kojem sebstvo nastaje ili u okviru kojega postoji (Stolorow i Atwood, 2002.), tada u kontekstu takva sistema postaju jasniji mnogi fenomeni i karakteristike sebstva koji se u izoliranoj slici sebstva čine neobjašnjivima. Ovo se u našem radu posebice odnosi na suvremeno sebstvo, za koje smatramo da posjeduje određene karakteristike specifične za suvremeno društvo u kojemu se formira i unutar kojeg egzistira. Intersubjektivna psihoanaliza, dakle, smatra da je interpersonalna dinamika ključna za razvoj individualnoga sebstva (Stolorow i Atwood, 2002.). S obzirom na to da je ona nastala na teorijskoj podlozi psihoanalitičke self-psihologije Heinza Kohuta, treba objasniti i tu konceptualizaciju radi lakšega razumijevanja suvremene organizacije sebstva.

Po Kohutovu mišljenju, upravo je responzivnost primarne okoline unutar koje sebstvo nastaje ono što će odrediti njegovu organizaciju (Kohut i Wolf, 1978.). Primarnu okolinu u kojoj se sebstvo formira čine roditelji ili neki drugi primarni staratelji, koje Kohut naziva "primarnim self-objektima".1 Sebstvo se razvija odnosima između njega i self-objekata uz pomoć procesa "transmutirajuće internalizacije" (Kohut i Wolf, 1978., 415). Razvoj se odvija u tri faze: 1) faza identifikacije i idealizacije, 2) faza manjih, netraumatskih disrupcija u responzivnosti idealizirajućih i identifikatornih self-objekata, 3) faza u kojoj te netraumatske disrupcije vode do postupne zamjene self-objekata i njihovih funkcija vlastitim funkcijama (Kohut i Wolf, 1978.). Moglo bi se, dakle, reći da dijete (sebstvo u nastajanju) odnos između primarnih staratelja i sebe uzima poput psihičke hrane za razvoj vlastite psihičke strukture, i to tako da: 1) stara- 
DRUŠ. ISTRAŽ. ZAGREB GOD. 20 (2011) BR. 2 (112),

STR. $561-580$

PASKA, I.: SUVREMENO SEBSTVO.. teljima pripisuje funkciju svemogućnosti, a budući da ne razlikuje sebe od njih, tada i samo iskazuje grandiozne tendencije koje bi roditelji trebali empatijski zrcaliti, 2) mehanizmom koji Kohut naziva "optimalnom frustracijom"2 dijete polako počinje shvaćati da staratelji također imaju granice i da staratelji i ono nisu jedno te time stvarati preduvjete za 3) "pounutrivanje" staratelja - razvijanje vlastite psihičke strukture internalizacijom funkcija koje su dotad za njega obavljali staratelji. Ako je dijete u toj fazi izloženo disrupcijama koje na traumatski način ometaju taj proces, poput nedostatka self-objekata, njihove nesposobnosti da zrcale njegove uspjehe ili da budu objekti idealizacije, ili njihove nemogućnosti da adekvatno odgovore na potrebe djeteta bar u prosječnoj mjeri, ono neće biti u stanju internalizirati funkcije self-objekta i stvoriti kohezivno sebstvo; ostat će manje ili više fragmentirano. Intersubjektivna psihoanaliza Stolorowa i Atwooda preuzima teorijsku koncepciju self-psihologije, ali naglasak stavlja na međuodnos staratelja i djeteta kao intersubjektivnoga sistema u kojemu se sebstvo razvija te daljnje intersubjektivne sisteme u okviru kojih ono postoji u toku života. U tom konceptu od jednakog su značenja i individualni svijet unutarnjeg iskustva osobe i njegova ukorijenjenost $u$ sistem drugih takvih svjetova (starateljskih te drugih self-objekata $\mathrm{u}$ toku života) $\mathrm{u}$ kontinuiranom toku recipročnoga obostranog utjecaja (Stolorow i Atwood, 2002.). U skladu s tim, u ovom se radu sebstvo promatra kroz postavke intersubjektivne psihoanalize koja "pokušava razumjeti psihološke fenomene ne kao proizvode izoliranih intrapsihičkih mehanizama, već kao fenomene koji se formiraju na sučelju recipročno međudjelujućih subjektivnosti" (Stolorow i Atwood, 2002., 3). Na taj se način naglasak stavlja ne samo na iskustvo individue nego i na "njezinu ukorijenjenost $\mathrm{s}$ drugima $\mathrm{u}$ stalnom toku međusobnoga međudjelovanja" (Stolorow i Atwood, 2002., 18). Drugim riječima, sebstvo je nužno određeno kontekstom u kojem se razvija i u kojem kasnije postoji.

Psihologinja Marks-Tarlow, konceptualizirajući sebstvo, rabi termin "sprega sebstava" kako bi opisala međudjelovanje dvaju sebstava u okviru kojih se stvara intersubjektivno polje sebstva. Koristeći se dinamskom teorijom, ona smatra da se prilikom odgoja događa koregulacija sebstava djeteta i roditelja - sebstvo roditelja koregulira ono djeteta i obratno, pri čemu reakcija onoga drugog predstavlja povratnu informaciju prvom te kao takva na njega utječe (Marks-Tarlow, 1999.). Osim na individualnoj razini, ta je sprega moguća i na razini kulture u cjelini. Kultura se također može smatrati "dinamskim sustavom koji sam sebe organizira", pa se sebstvo djeteta koregulira ne samo sa sebstvom odgajatelja nego i s fenomenom 
DRUŠ. ISTRAŽ. ZAGREB GOD. 20 (2011),

BR. 2 (112)

STR. $561-580$

PASKA, I.:

SUVREMENO SEBSTVO... kulture $\mathrm{u}$ širem kontekstu, što dovodi do fundamentalnih razlika u samoj jezgri organizacije sebstva, ovisno o kulturnom sistemu unutar kojega ono postoji (Marks-Tarlow, 1999.). Kao primjer, Marks-Tarlow navodi razliku između sebstava koja egzistiraju unutar zapadnoga kulturnog konteksta i onih u istočnim kulturama; dok u zapadnim kulturama ljutnja ima funkciju podržavanja individualističkih vrijednosti, u drugim kulturama njezina supresija ima funkciju podržavanja onih kolektivističkih. Sebstvo, dakle, ne nastaje u praznom prostoru, već se nužno formira u nekom intersubjektivnom kontekstu - kontekstu primarnih staratelja u užem smislu, a u kontekstu kulture $u$ širem smislu. Neizbježna implikacija takva razvoja jesu značajke određene kulture, koje - putem intersubjektivnog sistema koji je također ukorijenjen u nekom širem kulturalnom sistemu - postaju dijelom organizacijskih zahtjeva koje intersubjektivni sistem postavlja pred individualno sebstvo. Iz toga proizlazi da je sebstvo povezano s karakteristikama kulturnoga i povijesnoga konteksta društva unutar kojeg je nastalo.

Ovakav pristup naizgled se ne razlikuje od teorijske škole socijalnoga konstruktivizma, koji također smatra da je društvena okolina ono što stvara pojedinačno sebstvo. No jedna od glavnih kritika upućena socijalnom konstruktivizmu jest upravo "pretjerana racionalnost, svjesnost i kognicija" (Elliott, 2001., 29), jer on sudjelovanje sebstva u koregulaciji s okolinom ograničuje na svjesno djelovanje. Suvremena psihoanaliza ne stavlja toliki naglasak na svjesnu organizaciju iskustva unutar neke okoline, nego i dalje pridaje veliko značenje međudjelovanju okoline i nesvjesnoga - smatra se da se princip organizacije sebstva koji čini elementarnu građu za razvoj ličnosti organizira nesvjesno unutar sistema djeteta-staratelja (Stolorow i Atwood, 2002., 24). Ta se definicija u ovom radu proširuje tako da uključuje i kulturne sisteme, no ona nikako ne znači da je sebstvo pasivan proizvod nekoga društva ili kulture. Kultura, doduše, u toj koregulaciji jest u nekoj vrsti prednosti, jer sebstvo $\mathrm{u}$ fazi formacije nije dovoljno nezavisno da bi moglo svjesno upravljati svojim reakcijama na zahtjeve okoline. U tom je smislu njegova reakcija ograničena kulturom, no unutar tog ograničenja kreativni su načini organizacije vlastita iskustva stvar reakcije individue. Isto tako, u skladu s postavkama intersubjektivne psihoanalize, sebstvo u daljnjem životu uvijek ima mogućnost svjesne reorganizacije vlastita iskustva. Sebstvo je, dakle, do neke mjere svjesna, ali u najvećoj mjeri nesvjesna organizacija vlastita iskustva koja nastaje $u$ međudjelovanju s intersubjektivnom konfiguracijom self-objekata, a koja opet međudjeluje s kulturnim kontekstom unutar 
kojeg egzistira. ${ }^{3}$ Stoga je pokušaj razumijevanja sebstva koji ne promatra sebstvo u kontekstu intersubjektivnoga i kulturnoga sistema nastanka i egzistencije problematičan.

\section{SUVREMENO SEBSTVO I KRATKI KONTEKST NJEGOVA NASTANKA}

Potreba za proučavanjem utjecaja što ga suvremena kultura ima na sebstvo postala je osobito aktualna 1960-ih godina, kada je sve više psihoanalitičara bilo suočeno s novom vrstom pacijenata čiji su simptomi bili drukčiji od simptoma klasične freudovske neuroze (Lasch, 1986.). Psihoanalitičar Allen Wheelis primijetio je 1958. godine da se "promjena obrazaca neuroza" našla u "osobnom iskustvu starijih psihoanalitičara, dok su je mlađi postali svjesni primijetivši nesklad između starijih opisa neuroza i problema koje su svakodnevno iznosili pacijenti u njihovim ordinacijama" (Lasch, 1986., 47). Lasch navodi čitav niz primjedbi psihoanalitičara toga doba koje upućuju na to da su simptomatske neuroze mjesto ustupile karakternim poremećajima (Lasch, 1986.). Psihoanalitičar Michael Beldoch tad slikovito primjećuje da "većina današnjih pacijenata ne pati od histerične paralize noge ili prisilnoga pranja ruku, već su sama njihova psihička sebstva obamrla ili se moraju ribati uvijek iznova $u$ iscrpljujućem, beskonačnom naporu da postanu čista", pa zaključuje kako "ti pacijenti pate od prožimajućeg osjećaja ispraznosti i duboko narušenoga samopoštovanja" (Lasch, 1986., 48). Iako se prilikom primjenjivanja kliničkih pojmova na sveopću populaciju neizbježno javljaju neka ograničenja, ipak Lasch upozorava na svrhovitost takva pristupa, konstatirajući da svako doba razvija svoje posebne oblike patologije, koje u pretjeranom obliku izražavaju njegovu temeljnu karakternu strukturu (Lasch, 1986.). Kao što je viktorijansko doba zbog pokušaja kontrole "opasnih" impulsa u obliku seksualnih nagona iznjedrilo psihičke poremećaje poput histerije ili neurastenije (Cushman, 1990.), tako se temeljnim problemima suvremenoga doba smatraju - narcistički problemi (Lasch, 1986.). Upravo je stoga analiza formacije i egzistencije sebstva u suvremenom kontekstu nužna za razumijevanje tih problema.

Kako točno izgleda suvremena organizacija sebstva? Heinz Kohut 1960-ih je godina opisao tipično sebstvo s kakvim se najčešće susretao u kliničkoj praksi: pacijenta sa smetnjama koje je on jednim imenom nazivao narcističkima. Iako ta dijagnoza uključuje širok spektar simptoma te postoji više podvrsta, ipak su svima zajedničke neke karakteristike: disrupcije u samopouzdanju, nemogućnost da se održi pozitivan i stabilan osjećaj vlastita identiteta, krhkost osjećaja vlastite vrijednosti te krajnja nepostojanost samopouzdanja i raspoloženja koja uglavnom ovise o vanjskim podražajima u obliku pohvala ili kritika (Magid, 2005., 18). Osim toga, aktualni su i problemi hi- 
DRUŠ. ISTRAŽ. ZAGREB GOD. 20 (2011),

BR. 2 (112)

STR. $561-580$

PASKA, I.:

SUVREMENO SEBSTVO... pohondrije, seksualni problemi ili problemi sa slikom vlastita tijela, koji se također javljaju u trenutku disrupcije mentalne reprezentacije sebstva. Iza pacijentove grandiozne fasade obično se krije pervazivan osjećaj praznine, depresije ili "razbijenosti" (Magid, 2005., 18). Grandioznost ovdje ima obrambenu funkciju održanja strukture poricanjem ranjivosti i agresije koja proizlazi iz osjećaja bespomoćnosti, ostavljanjem tih osjećaja koji se za fragmentirano sebstvo čine opasnima, izvan domene svjesnoga. Takvo cijepanje svjesnoga i nesvjesnoga dijela čine ono što su još psihoanalitičari Winnicott i Fairbairn prozvali "lažnim sebstvom" (Johns, 2005., 546).

Kohut je također primijetio da navedeni pacijenti ne prolaze dobro u klasičnoj analizi jer ne razvijaju klasične edipske prijenose. Umjesto toga, oni tendiraju razvoju prijenosa u kojemu bi terapeut predstavljao idealiziranu roditeljsku figuru s kojom pokušavaju stvoriti emocionalnu poveznicu (Magid, 2005., 18). Skloni su i vrlo uskom definiranju potencijalnih self-objekata i arhaičnom vezivanju sa njima umjesto zrelom; arhaične vrste prijenosa koje su karakteristične za narcističke tendencije vrlo su krhke, pa u slučaju najmanjega znaka nerazumijevanja s druge strane iskustvo se može urušiti (Magid, 2005.). Na temelju svoje kliničke prakse, Kohut je zaključio da postoji razlika između strukture sebstva iz 19. st. i one koju je on primjećivao 1960-ih i 1970-ih godina. Dok je kraj 19. i početak 20. st. bio obilježen pojedincem opterećenim krivnjom, osobom koja je bila rezultat emocionalne zatvorenosti i rigidnosti u obiteljskim odnosima 19. st., moderni je pojedinac bio proizvod nukleusne obitelji na kojem se odražavala premala stimulacija u skladu sa smanjenjem obitelji i povećanim radnim vremenom roditelja zbog industrijalizacije (Kohut, 1977.). Dakle, dok je tipični pojedinac Freudova doba patio od edipskih osjećaja krivnje, tipični pojedinac Kohutova doba do te faze nije uspio ni doći, jer se suočio s traumatičnom frustracijom već u prededipovskom razdoblju, pa je uglavnom patio od narcističkih problema, poput prazne depresije ili težnje $\mathrm{k}$ fragmentaciji. ${ }^{4}$ Kako bi ga se bolje moglo razumjeti, valja detaljnije razmotriti na koje je načine suvremeni kulturni i intersubjektivni kontekst povezan $\mathrm{s}$ takvim promjenama u organizaciji sebstva.

\section{SUVREMENI INTERSUBJEKTIVNI I DRUŠTVENO-KULTURNI KONTEKST SEBSTVA}

Kako su, dakle, promjene u suvremenom društvenom kontekstu povezane s promjenama u organizaciji sebstva?

Kad je riječ o primarnom intersubjektivnom kontekstu formacije sebstva - obitelji, neizbježno moramo pretpostaviti da su promjene u obiteljskoj strukturi u zadnja dva stoljeća utjecale i na sebstvo. Promjena obiteljske forme iz proširene obitelji prema nukleusnoj mora pružati potpuno drukčiji inter- 
DRUŠ. ISTRAŽ. ZAGREB GOD. 20 (2011) BR. 2 (112),

STR. $561-580$

PASKA, I.: SUVREMENO SEBSTVO.. subjektivni kontekst u suvremenom društvu od onoga u prethodnim razdobljima. Tako se u Americi postotak kućanstava sa 7 ili više osoba spustio sa 35,9\% u 1790. godini na 5,8\% u 1950 . godini (Cushman, 1990.). U suvremenim uvjetima, najmanje 50\% djece u Americi provest će bar dio djetinjstva u obitelji s jednim roditeljem (Teachman i sur., 2000.). Europske statistike pokazuju slične trendove, pa tako 2004. na 2,2 milijuna brakova dolazi čak 1 milijun rastava, što znači da na svaka dva braka dolazi gotovo 1 rastava (Eurostat, 2006.). Jednako tako, europski trend poput američkoga pokazuje promjene $\mathrm{u}$ formi obitelji, pri čemu je posebno istaknut trend porasta samohranoga roditeljstva (Daly, 2005.). Iako se čini da su ovi trendovi karakteristični za obitelj Sjeverne Amerike i zapadne Europe (Daly, 2005.) te da obiteljske strukture svake zemlje imaju svoje specifičnosti, ipak se primjećuje da te trendove slijede i ostale europske zemlje, pa i Hrvatska (Puljiz, 1995.). Promjene u obiteljskim formama dovele su do raznih nuspojava, kao što je potpun gubitak kontakta s jednim roditeljem, ponovno sklapanje braka i kompleksne nove obiteljske forme s često velikom količinom ambivalentnosti i nedostatkom jasnih definicija uloga (Hagestad, 1988., 408). Kada sudionicima takvi obiteljski odnosi postaju prekompleksni, oni se često obraćaju za pomoć stručnjacima (Hagestad, 1988., 408). Na tragu toga treba napomenuti da su obiteljski odnosi u današnje vrijeme općenito rezultat procesa koji je prije više od stoljeća, zbog sve veće institucionalizacije društva, počeo institucionalno regulirati i obiteljske odnose (Lasch, 1986.; Cushman, 1990.). Kroz taj proces javilo se više pojava koje intersubjektivni obiteljski sistem čine manje adekvatnim za proces optimalne frustracije (Lasch, 1986.) koji omogućuje stjecanje kohezivnoga sebstva (Meronen, 1999.). Ti se procesi i promjene koje oni uzrokuju uočavaju i u obiteljima koje ostaju u obliku nukleusne obitelji.

Prvi je od tih procesa odvajanje radnoga prostora od kućnoga (Sennett, 1989.). S obzirom na to da suvremena nukleusna obitelj uključuje oba zaposlena roditelja (Puljiz, 1995.), djeca na taj način ostaju prepuštenija sama sebi i imaju manje prilike za provođenje vremena s roditeljima, što daje manju mogućnost identifikacije s roditeljima. $S$ druge strane, u privatnom prostoru roditelji i djeca više nisu odvojeni kao u proširenim obiteljima, što djecu uključuje u odnos roditelja i eventualne emocionalne probleme roditelja (Riesman i sur., 1965.). Stoga bismo mogli zaključiti da je već prilika za idealizaciju roditelja, koja je prvotni korak u procesu optimalne frustracije, upitna. Nadalje, ni roditelji se više ne osjećaju superiornima u odnosu na djecu. U suvremenom svijetu medijskih okoliša djeci znanje postaje dostupno i mimo roditelja. Djeca tako stječu neka znanja koja roditelji i nemaju (Riesman i sur., 
DRUŠ. ISTRAŽ. ZAGREB GOD. 20 (2011), BR. 2 (112),

STR. $561-580$

PASKA, I.: SUVREMENO SEBSTVO...
1965.). Možemo pretpostaviti da takav okoliš ne pruža isti osjećaj stabilnosti, kontinuiteta i dostupnosti self-objekta za "pounutrenje" kakav je nekad pružala tradicionalna forma obitelji. Stoga se promjene $\mathrm{u}$ formi obitelji mogu povezati s promjenama u organizaciji sebstva.

Institucije "ulaze" u obiteljske odnose i na druge načine. Lasch primjećuje kako se javila institucionalizacija odgoja djece, što istodobno ruši roditeljski autoritet i na njih vrši pritisak da se ponašaju prema određenoj formi koja se smatra superiornima vlastitim autentičnim osjećajima (Lasch, 1986.) Roditelji više nisu sigurni u to koji je ispravan način odgoja djeteta, to više što se vode institucionaliziranim perspektivama raznih priručnika ili uputama iz medija, koje odlikuje višestrukost perspektiva (Riesman i sur., 1965.). Shodno tome, budući da se $\mathrm{u}$ odgoju djeteta tuđe mišljenje uzima kao superiorno $u$ odnosu na vlastite osjećaje, veća se pažnja poklanja vanjskim formama ponašanja nego kontaktu s vlastitim, autentičnim osjećajima. Naša je pretpostavka da takve okolnosti pogoduju stvaranju okoline koja otežava prepoznavanje vlastitih autentičnih osjećaja. Prepoznavanje autentičnih osjećaja neki psiholozi nazivaju kognitivnom dostupnošću pravoga sebstva (Schlegel i sur., 2009.). Upravo je nedostupnost autentičnih osjećaja jedan od glavnih problema narcističkoga sebstva koju je uočio Kohut (Kohut, 1990.), a koju su Stolorow i Atwood kasnije povezali s intersubjektivnim kontekstom. Ona iskustva koja se unutar nekoga intersubjektivnog konteksta osjećaju neprihvatljivima ili preopasnima isključuju se iz organizacije iskustva (Stolorow, 2000., 150). To ne znači da ona nestaju, nego tako disocirana počinju predstavljati potencijalne simptome.

Valja uzeti u obzir da se narcistička struktura sebstva u kliničkoj praksi primjećuje još od šezdesetih godina 20. st. To ujedno znači da su današnje generacije roditelja u svojoj razvojnoj fazi također bile izložene sličnim kulturnim uvjetima formacije sebstva te da se i oni susreću s modernim kontekstom egzistencije sebstva. Iz toga proizlazi da možda ni sami nemaju osobito kohezivnu strukturu sebstva te da imaju smanjen kapacitet da budu stabilni self-objekti. Lasch primjećuje kako roditelji suvremene djece također tendiraju narcističkim značajkama te da često iskorištavaju vlastitu djecu za nadoknađivanje potreba za primarnim self-objektima koje nisu bile do kraja zadovoljene u djetinjstvu (Lasch, 1986.). Lako je predvidjeti kako se ciklus problema s kojima se susreće moderna obitelj na taj način prenosi s generacije na generaciju.

No nije samo primarni intersubjektivni kontekst ono što stvara narcističko sebstvo modernoga doba. Ako se organizacija sebstva tijekom života konstantno reorganizira te je određuje i daljnji kontekst unutar kojeg postoji u ostatku života 
DRUŠ. ISTRAŽ. ZAGREB GOD. 20 (2011)

BR. 2 (112),

STR. $561-580$

PASKA, I.:

SUVREMENO SEBSTVO..
(Stolorow i Atwood, 2002.), legitimno je pitanje što u suvremenom kulturnom kontekstu pridonosi njegovoj fragmentiranosti.

Narcistička organizacija sebstva može se shvatiti i kao vrsta obrambenoga mehanizma koja sebstvo štiti od sve veće anksioznosti kojemu je ono izloženo u procesima modernosti (Lasch, 1986.). U globaliziranom društvu bitno se pojačava osjećaj diskontinuiteta vremena, prostora i identiteta, što kod pojedinca pojačava osjećaj egzistencijalne nesigurnosti (Giddens, 1991., 37). No čini se kako su takve radikalne promjene u strukturi sebstva uvijek odraz nekih dugotrajnijih promjena u samoj strukturi društva. Da bismo razumjeli povezanost između strukture društva i strukture sebstva, treba za početak pobliže opisati razliku između nekadašnjega i modernoga sebstva.

Pritom je nužno napomenuti da se percepcija i samopercepcija sebstva današnjice bitno razlikuju od one u prijašnjim povijesnim razdobljima. Za razliku od 18. stoljeća, u kojemu su se ljudi još promatrali u terminima karaktera i moralnih izbora, u 19. st. počinju se promatrati u terminima osobnosti i emocionalnih sila (Lasch, 1986.). Dok je karakter stavljao naglasak na opće elemente ljudske prirode, osobnost se promatra prije u smislu vanjskih, osebujnih značajki. Naglasak se također stavlja više na upravljanje vanjskim dojmovima i oblikovanje vlastite osobnosti, umjesto na unutrašnji osjećaj sebstva (Sennett, 1989.; Lasch, 1986.). Philip Cushman ovako opisuje taj fenomen:

"... osobito u Americi, potraga za razvojem sekularne osobnosti nadišla je izgradnju moralnoga karaktera. Za razliku od karaktera, kojega je centar osobni moralni integritet, bontoni toga doba tvrdili su da je osobnost sinonim za to koliko vas drugi ljudi vole. Sebstvo se počelo promatrati kao nešto što se može mijenjati vlastitim snagama; impresioniranje drugih i stjecanje njihova odobravanja postalo je važnim ciljem u životu, daleko nadjačavajući vrijednost rađenja moralno ispravnoga čina koji je prije usmjeravao nečiji karakter" (Cushman, 1990., 602).

Takva promjena kvalitativnih odrednica sebstva nije bila kratkotrajan proces. Ona se prije svega povezuje s promjenama u društvenoj strukturi povezanima s industrijalizacijom (Durkheim,1984.; Baumeister, 1987.; Cushman, 1990.), iz čega proizlazi da traje već više od dvjesto godina. Sociologinja Irena Taviss Thomson novu formu sebstva povezuje is nešto kasnijim ekonomskim strukturama koje su se pojavile u prva dva desetljeća 20. st., a koje su predodredile novu vrstu poželjnoga sebstva; "dok je pojedinac s dobrim 'karakterom' bio moralan, iskren, predan i marljiv, onaj s dobrom 'osobnosti' dobro se slagao s drugima, u njegovu je društvu bilo zanimljivo i uspješno je iskazivao individualnost" (Taviss Thomson, 1989., 864). 
DRUŠ. ISTRAŽ. ZAGREB GOD. 20 (2011), BR. 2 (112)

STR. $561-580$

PASKA, I.: SUVREMENO SEBSTVO...
Takvu vrstu sebstva nije teško povezati s novorazvijenim ekonomskim fenomenima, poput oglašavanja, prodaje i odnosa s javnošću, koji su se u većoj mjeri razvili upravo dvadesetih godina 20. stoljeća, te zahtjevima prilagodljivosti vanjskim okolnostima koje pred osobu postavlja kapitalistički sustav, a za koje je moralni karakter bio suviše nefleksibilan (Taviss Thomson, 1989.). I drugi autori povezuju nove karakteristike sebstva s kapitalističkim strukturama (Cushman, 1990.; Riesman i sur., 1965.). Pedesete i šezdesete godine 20. st. nastavile su ovaj trend razvoja osobnosti; tehnološki razvoj i velike birokracije zahtijevale su još veću osobnu fleksibilnost, a od pojedinaca se tražilo da se brzo prilagođavaju stalnim promjenama okoline te da ga pokušavaju kontrolirati manipuliranjem emocionalnih potreba drugih (Taviss Thomson, 1989.). Riesman, Glazer i Denny 1960-ih godina ustvrđuju kako se u Americi razvio novi tip društvenoga karaktera. Dok je stari tip bio "usmjeren prema unutra" te se u ponašanju vodio smjernicama koje je naučio u djetinjstvu, karakterizirao ga je dobar osjećaj vrijednosti i manje fleksibilna struktura, noviji tip pojedinca "usmjerenoga prema van" svoje sebstvo organizira prema onome što rade drugi; kod njega mjerilo stavova, osjećaja i ponašanja postaju drugi (Riesman i sur., 1965.). Potonji tip pojedinca oni također povezuju s društvom koje je u većoj mjeri institucionalizirano.

Možemo pretpostaviti da takva pretjerana usmjerenost na vanjske forme dovodi do veće formalizacije ponašanja. Sebstvo koje je u većini društvenih interakcija prisiljeno upravljati vanjskim dojmovima postupno će se početi poistovjećivati s njima, što ne pogoduje kognitivnoj dostupnosti pravoga sebstva. Iz navedenoga postaje jasnije kako suvremene društvene strukture pogoduju razvoju "lažnoga sebstva", tipičnog za narcističku organizaciju. Indikativno je i to da se u 1960-ima javljaju upravo one psihoterapije koje patologiju doživljavaju kao manjak kontakta s cjelovitim spektrom vlastitih osjećaja, a u terapiji rade na ponovnoj uspostavi toga kontakta: osim psihoanalitičke self-psihologije, tada se razvijaju još i Perlsova gestalt-psihoterapija i Rogersova humanistička psihologija.

Tehnološki napredak društva također je faktor koji valja uzeti u obzir u analizi struktura koje pogoduju razvoju lažnoga sebstva. Moderni medijski fenomeni veći naglasak stavljaju na vanjski dojam nego na sadržaj. Psiholog Kenneth Gergen 1990-ih godina primjećuje da tehnološki napredak proizvodi radikalan pomak u načinu na koji smo izloženi drugima (Gergen, 1992.). Tomu treba dodati da se na početku 21. st. javljaju oblici tehnoloških organizacija koji omogućuju ekstremno upravljanje vanjskim dojmovima. Na internetu izgradnja vlastite osobnosti postaje doslovni projekt: profil na društve- 
DRUŠ. ISTRAŽ. ZAGREB GOD. 20 (2011)

BR. 2 (112),

STR. $561-580$

PASKA, I.:

SUVREMENO SEBSTVO.. noj mreži postaje nekom vrstom svetišta modernoga sebstva, projektom čija se uspješnost mjeri u količini prijatelja koju je sebstvo uspjelo privući. I ovdje primjećujemo naglasak na vanjskoj formi odnosa umjesto na sadržaju, što i opet stvara okoliše pogodne za razvoj narcističkih struktura sebstva. Sebstvo na internetu postaje lako kontrolirajući projekt kojim se može upravljati uspješnije nego u stvarnom životu. O sebstvu kao o projektu također će biti govora kasnije u radu.

No navedene društvene promjene odraz su promjena $u$ dubljim društvenim instancama, započetim još procesom industrijalizacije prije više od dva stoljeća. Stoga treba istražiti koje su to dublje društvene instance koje su, kao rezultat dugotrajnoga procesa modernizacije društva, danas potencijalno povezane i s promjenama strukture sebstva.

\section{PROMJENA U DRUŠTVENIM INSTANCAMA KOJE SEBSTVO POVEZUJU S DRUŠTVOM}

Postoje neke društvene instance čiju bismo kvalitativnu promjenu mogli povezati s promjenama strukture sebstva; to su vrijednosti, moral, ideali i autoriteti. Iako definicije tih instanci u društvenim znanostima nisu sasvim jasno određene, ipak one posjeduju jednu zajedničku karakteristiku - povezivanje pojedinca s društvom. Ni jedna od njih nema izvorište izravno u pojedincu, nego ih pojedinac dobiva od društva koje se njima koristi kako bi mu dalo smjernice za život u skladu s kulturom određenoga razdoblja - povijesnoga ili geografskoga kojoj pripadaju.

Roy Baumeister smatra da vrijednosti u modernom vremenu sve više poprimaju individualni karakter. Dok su se nekad vrijednosti promatrale kao "objektivne istine koje konsenzusom dijeli neka kultura, sada se one gledaju kao rezultat naoko arbitrarnih izbora koji nemaju čvrstu ili objektivnu bazu" (Baumeister, 1992., 24). Bellah, Madsen, Sullivan, Swidler i Tiption ustanovili su istraživanjem na američkoj populaciji da ispitanici nisu kadri opravdati svoje životne odluke bez reference na svoje sebstvo, što je istraživače navelo na zaključak da "svako sebstvo konstituira svoj vlastiti moralni univerzum" (Schlegel i sur., 2009., 474). Iako je izrazita individualnost karakteristična za američku kulturu, ipak je sve veća individualizacija i time uzimanje vlastitog "ja" kao referentne točke fenomen općenito povezan s modernizacijom društva, koji je sociologijskoj znanosti poznat još iz radova klasične sociologije.

Još je Emile Durkheim individualno sebstvo koje se percipira kao individualno od društva povezao sa sve većom specijalizacijom društva na području rada, zbog koje opada mehanička solidarnost (solidarnost za koju je karakterističan tip kolektivne svijesti kao temelj moralnoga poretka) i razvija se organska 
DRUŠ. ISTRAŽ. ZAGREB GOD. 20 (2011), BR. 2 (112)

STR. $561-580$

PASKA, I.: SUVREMENO SEBSTVO... solidarnost (solidarnost za koju je karakterističan tip individualne svijesti i nužnost pronalaska novoga temelja moralnoga poretka) (Durkheim, 1984.). Moralnost za Durkheima nije individualno inherentni fenomen, nego fenomen koji svoje izvorište ima u društvu, u "povezanosti s nečim što je veće od nas" (Emirbayer, 2003.). Iz te perspektive postaje jasno koliko je problematičan zadatak individualnog određivanja moralnosti s kojim se suočava suvremeno sebstvo. Taviss Thomson kao primjer navodi priručnike za samopomoć iz sedamdesetih godina 20. st., koji pojedincu jasno kazuju da je "'moralnost ... vrlo privatna i osobna stvar', a ideje dobra i zla samo su sudovi koji se temelje na vlastitim preferencijama" (Taviss Thomson, 1989.). Možemo pretpostaviti kako zahtjev da se moralnost, koja je po definiciji društvenog izvorišta, pronađe $\mathrm{u}$ sebi stavlja pred pojedinca paradoksalan zadatak koji može dovesti do neke vrste egzistencijalne nesigurnosti. Psihoanalitički gledano, ako je takvo iskustvo pretraumatično, ono može uzrokovati potrebu psiholoških obrana u obliku poricanja samog iskustva nesigurnosti (također, vrsta "cijepanja").

O društvenim idealima njemački sociolog Georg Simmel još na početku 20. stoljeća konstatira kako "čovječanstvo već desetljećima ne živi pod nekom krovnom idejom kao trajnom" (Simmel, 2001.). Za prijašnja je doba u povijesti bio karakterističan neki ideal koji je odražavao osnovnu paradigmu po kojoj se živjelo u tom razdoblju: za kršćanski vijek to je bio pojam Boga, za 17. st. pojam prirode kao ideala, u 18. st. vladali su prosvjetiteljstvo i razum te smjernice njemačkog idealizma. No za moderno je doba karakteristično upravo nepostojanje takva jasnog, prevladavajućeg ideala ili ideje (Simmel, 2001.). Kad bi se ljude upitalo pod kojom idejom danas žive, "rijetko bi se čulo nešto o ideji kulture koja bi njima vladala kao ljudima, većina bi navela neki specijalistički odgovor iz svojega zanimanja" (Simmel, 2001., 93). Moglo bi se reći da pojedincima nedostaje ono što Riesmann, Glazer i Denny slikovito nazivaju "internaliziranim idealom" (Riesman i sur., 1965. 107). Taviss Thomson navodi kritičare društva koji 1970-ih godina primjećuju kako društvo pati od "odbijanja idealizacije" - nedostatka ideala, heroja i zajedničke svrhe (Taviss Thomson, 1989., 856).

Iz svega navedenog možemo zaključiti da suvremeno doba, za razliku od prijašnjih, pojedincima ne daje unaprijed određeni vrijednosni ili moralni kontekst, nego se od njih očekuje da taj kontekst sami osmisle. Iako se na taj način otvara prostor novih mogućnosti osmišljavanja vlastita života, ipak on, s druge strane, izaziva određenu dozu anksioznosti koja u prethodnim povijesnim razdobljima nije postojala. Primjećujemo da je tendencija anksioznosti pogotovo vjerojatna u kontekstu ka- 
DRUŠ. ISTRAŽ. ZAGREB GOD. 20 (2011) BR. 2 (112),

STR. $561-580$

PASKA, I.: SUVREMENO SEBSTVO... pitalističko-tehnološkoga društva, koje se po definiciji više usmjeruje na formu nego na sadržaj - ljude promatra kao objekte zarade prije nego kao subjekte. Stoga ona propušta pojedinca opskrbiti smjernicama za pronalazak konteksta smislene egzistencije.

Istodobno Lasch primjećuje kako je moderno društvo uništilo sve autoritete (Lasch, 1986.). Sam pojam autoriteta postao je upitan, pa unutar obiteljskoga intersubjektivnog sistema roditelji više ne pokušavaju biti toliko autoriteti koliko prijatelji vlastitoj djeci (Lasch, 1986.). Taviss Thomson zamjećuje kako moderna prilagodljiva sebstva imaju manje poštovanja prema društvenim institucijama i sklonija su demistifikaciji društva. Tomu dodatno pridonosi povećan broj obrazovanih, povećan broj dostupnih izvora informacija, te razvoj znanosti. U isti mah povećana potreba za fleksibilnošću i promjenjivošću čini društvenu i institucionalnu sferu vrlo nepouzdanim izvorom "sidrenja" sebstva (Taviss Thomson, 1989.).

Generalno gledajući, možemo ustvrditi kako se takav kronični manjak društvenih instanci koje bi pojedinca povezale s nečim što nije on sam može povezati s nestabilnijom strukturom sebstva. Nemogućnost "pounutrenja" društvenih instanci također može biti jedna od interpretacija uzroka osjećaja praznine kao jedne od glavnih značajki narcističkih struktura sebstva.

Sociolog Anthony Giddens sebstvo u modernosti promatra kao refleksivni projekt. $U$ postmodernom vremenu sebstvo više nije dano, ono se konstruira kao narativni projekt (Giddens, 1991.). Takva konstrukcija sebstva omogućuje programe aktualizacije i ovladavanja sebstvom, no toliko dugo dok su ti programi samo produžetak kontrolnih sistema modernosti, oni su bez moralnoga značenja (Giddens, 1991., 9). Refleksivno shvaćanje vlastita života teško može pridonijeti kohezivnosti sebstva ako samo nije ukorijenjeno u društvenoj mreži značenja. Giddensovi "programi aktualizacije" bez značenja mogu se tako povezati s praznim kulturnim formama koje je Simmel primijetio još na početku 20. stoljeća. Još tada on konstatira kako je diskrepancija između objektivne kulture (u ovom slučaju praznih kulturnih formi) i subjektivne kulture (ostvarivanja vlastita potencijala) osobito izražena u moderno vrijeme (Simmel, 2001.). Vanjske kulturne forme u modernom se društvu, zbog složenosti birokracije i institucija kojima se ono prisiljeno služiti, opredmećuju i postaju "carstva kojima se upravlja po njihovim vlastitim zakonima i koja traže da budu sadržaj i norma individualne egzistencije koja zapravo ne zna što bi s njima i, štoviše, prilično ih često osjeća kao opterećenja i neprijateljske snage" (Simmel, 2001., 73). Drugim riječima, materijalna je kultura u suvremenom društvu u tolikoj mjeri zadobila vlastiti život da on više ne služi zadovoljenju 
DRUŠ. ISTRAŽ. ZAGREB GOD. 20 (2011), BR. 2 (112)

STR. $561-580$

PASKA, I.: SUVREMENO SEBSTVO... potreba individualnoga sebstva, nego stvara niz pravila koja često nisu uopće prilagođena individualnom sebstvu i svode se na niz pukih formi nepovezanih sa sadržajem. Može se reći da Giddensovi programi aktualizacije sebstva, koji se svode na puki kontrolni sistem modernosti, predstavljaju svojevrsnu društvenu formu koja je sadržajno osiromašena. Moderno društvo (često čak i institucionalno) nameće potrebu za samorefleksijom, međutim iz razloga koje smo prije napomenuli promjene $\mathrm{u}$ prirodi vrijednosti, morala, ideala i autoriteta - ne nudi sredstva bogata značenjima koja bi samorefleksiji dala smislenost. Kao posljedica susreta s takvim formama u pojedinca se javlja osjećaj besmislenosti, pa onda i praznine. No valja napomenuti da je Giddens optimističan te smatra da se kao kontrareakcija tom fenomenu javljaju novi pokreti (poput spiritualnih, ekoloških ili feminističkih pokreta), koji artikuliraju upravo ona moralna pitanja koja institucije modernosti potiskuju (Giddens, 1991.).

Ipak, iz svega navedenog može se zaključiti kako su promjene $u$ strukturi suvremenoga društva razorile nekad jasniju i jaču vezu između pojedinca i društva, a formalizirana svakodnevica prilagođena institucionalnom i ekonomskom životu nije ju nadoknadila novima jednake stabilnosti. Istodobno, proces internalizacije značajnih figura u životu osobe postaje otežan, prije svega zato što se većina značajnih figura i sama bori s kontekstom modernosti, a onda i zato što moderni kontekst ne ostavlja mnogo prostora za idealizaciju. Manjak internaliziranog ideala također proizlazi iz manjka prevladavajućeg ideala, situacije karakteristične za moderno doba, a autoriteti su izgubili na jakosti koju su imali u tradicionalnim društvima. S obzirom na to da su spomenute društvene instance uglavnom veza između pojedinca i društva, pa mu uz osjećaj pripadanja daju i osjećaj stabilnosti, manjak tih instanci može se shvatiti kao kontekst pogodan za nastanak strukture sebstva s težnjom prema fragmentaciji.

\section{ZAKLJUČCI I IMPLIKACIJE}

U radu je kontekstualnom analizom formacije i egzistencije sebstva upozoreno na problematičnost akontekstualnoga pristupa koji sebstvo promatra izolirano od okoline. Sebstvo se ovdje promatra kao organizacija iskustva koja nastaje u međudjelovanju s užim, intersubjektivnim, kontekstom te tijekom života egzistira u okviru nekih intersubjektivnih sistema i kulture kao širega sistema. Stoga je za njegovo potpuno razumijevanje nužna kontekstualna perspektiva. Slijedeći tu teoretsku pretpostavku, klinički nalazi fragmentiranoga pojedinca koji se u psihijatrijskoj praksi zamjećuju od 1960-ih godina, u ovom se radu povezuju s promjenama u suvremenom društvenom i kulturnom kontekstu. Promjene $\mathrm{u}$ formi obitelji, u o- 
DRUŠ. ISTRAŽ. ZAGREB GOD. 20 (2011) BR. 2 (112),

STR. $561-580$

PASKA, I.: SUVREMENO SEBSTVO.. sjećaju stabilnosti što ga pruža društvo, u tehnološkim okolišima te općenito u kvalitativnim odrednicama koje se smatraju sebstvom povezuju se s promjenama u organizaciji sebstva. One su shvaćene i kao odraz promjena na razini dubljih društvenih struktura: vrijednosti, ideala, morala i autoriteta. Nestanak jasnoga vrijednosnog orijentira, internaliziranog ideala, jasnih moralnih odrednica i korozija autoriteta koji je $\mathrm{u}$ tradicionalnim društvenim strukturama bio jak predstavlja kontekst koji pogoduje nastanku nestabilnije strukture sebstva; sebstva sklonoga fragmentaciji. Možemo reći da se ovakvim prikazom daje makrosociološki kontekst Kohutovu fragmentiranom pojedincu, zamijećenom u kliničkoj praksi.

$\mathrm{Na}$ kraju, potrebne su i neke napomene u svezi s prirodom ovoga rada. $S$ obzirom na to da se u njemu rabi interdisciplinarni pristup koji ujedno objedinjuje mikroperspektivu i makroperspektivu društva, valja očekivati da će se takva kompleksnost pristupa platiti cijenom metodološke nepreciznosti. Stoga ovaj rad treba promatrati u prvom redu kao teorijski okvir koji pruža mogućnosti za detaljniju razradu ove teme. Treba napomenuti i to da je iz namjere rada isključena svaka vrijednosna evaluacija društvenih uvjeta u određenim razdobljima. Iako se iz ovakva prikaza čini da je suvremeni društveni kontekst ono što uzrokuje fragmentiranost suvremenoga sebstva, ne treba zaboraviti ni to da on pruža mogućnosti za samoostvarenje koje nisu postojale $\mathrm{u}$ tradicionalnim društvenim strukturama. Stoga ovaj rad ne treba shvatiti kao konzervativnu kritiku suvremenoga društva, nego prije kao postavljanje temelja za razumijevanje poteškoća s kojima se susreće suvremeno sebstvo koje egzistira unutar njega.

\section{BILJEŠKE}

1 "...self-objekti su objekti ili funkcije koje izazivaju osjećaj sebstva, održavanja sebstva ili pozitivnog utjecaja na sebstvo (Suesske, 2004., 95).

2 Proces optimalne frustracije jesu netraumatska razočaranja u svemogućnost roditelja koja se postižu njihovom "odsutnošću, propustima, razočaranjima u njih i podnošenjem odgovornosti u skladu s godinama" (Goldberg, 2005., 1798).

$3 \mathrm{~S}$ obzirom na drukčije ontološko poimanje sebstva u različitim disciplinama, možda treba napomenuti da se ontološki pojam "sebstva" u ovom radu podudara sa psihoanalitičkim shvaćanjem sebstva od Kohuta nadalje. Pojam sebstva u ovom radu bliže je fenomenološkom shvaćanju sebstva kakvo je karakteristično za psihoanalitičku self-psihologiju te intersubjektivnu psihoanalizu, za razliku od reprezentativnoga shvaćanja sebstva koje je bliže socijalnoj i kognitivnoj psihologiji. "Sebstvo je za Kohuta način na koji osoba doživljava sebe kao sebe, trajna mentalna struktura koja se sastoji od osjećaja, sjećanja i ponašanja koja se subjektivno doživljavaju kao kontinuirani u vremenu i kao 'biti ja'. Sebstvo je i 'osjećani centar inicijative' i 'nezavisni primatelj dojmova' - centar individualnoga psihološkog univerzuma, a ne samo puka reprezentacija" (Corbett, 1989., 1). 
DRUŠ. ISTRAŽ. ZAGREB GOD. 20 (2011),

BR. 2 (112)

STR. $561-580$

PASKA, I.:

SUVREMENO SEBSTVO...
${ }^{4}$ Fragmentacija - osjećaj anksioznosti pri kojemu se čini da se sebstvo "raspada na dijelove" (Oppenheimer, 2005., 605), arhaični mehanizam obrane koji je prva opisala Melanie Klein, javlja se kao obrana od onoga što se organizmu čini kao prijetnja "anihilacijom" (Palacio Espasa, 2005., 102). Fragmentirano sebstvo u kliničkoj je dijagnostici suprotnost kohezivnom.

\section{LITERATURA}

Baumeister, R. F. (1987.), How the Self Became a Problem: A Psychological Review of Historical Research. Journal of Personality and Social Psychology, 52 (1): 163-176. doi:10.1037//0022-3514.52.1.163

Baumeister, R. F. (1992.), Neglected Aspects of Self Theory: Motivation, Interpersonal Aspects, Culture, Escape, and Existential Value. Psychological Inquiry, 3 (1): 21-25. doi:10.1207/s15327965pli0301_3

Corbett, L. (1989.), Kohut and Jung: A Comparison of Theory and Therapy. U: D. W. Detrick i S. B. Detrick (ur.), Self Psychology: Comparisons and Contrasts, Hillsdale-NJ, The Analytic Press, dostupno na: http:// www.findingstone.com/professionals/monographs/kohutandjung.htm (29. 4. 2009.)

Cushman, P. (1990.), Why the Self is Empty: Towards a Historically Situated Psychology. American Psychologist, 45 (5): 599-611. doi:10.1037// 0003-066X.45.5.599

Daly, M. (2005.), Changing Family Life in Europe: Significance for State and Society. European Societies, 7 (3): 379-398. doi:10.1080/146166 90500194001

Durkheim, E. (1984.), The Division of Labor in Society, New York: Free Press. Elliott, A. (2001.), Concepts of the Self, Cambridge: Polity Press.

Emirbayer, M. (2003.), Emile Durkheim: Sociologist of Modernity, Oxford: Blackwell Publishing.

Eurostat (2006.), The Family in the EU25 Seen through Figures, 6, dostupno na http://epp.eurostat.ec.europa.eu/cache/ITY_PUBLIC/3-12052006AP/EN/3-12052006-AP-EN.PDF (29. 4. 2009.)

Gergen, K. (1992.), The Saturated Self: Dilemmas of Identity in Contemporary Life, New York: Basic Books.

Giddens, A. (1991.), Modernity and Self-Identity: Self and Society in the Late Modern Age, Cambridge: Polity Press.

Goldberg, A. (2005.), Transmuting Internalization. U: A. De Mijolla (ur.), International Dictionary of Psychoanalysis (str. 1798), New York, Thomson-Gale.

Hagestad, G. O. (1988.), Demographic Change and the Life Course: Some Emerging Trends in the Family Realm. Family Relations, 37 (4): 405-410. doi:10.2307/584111

Johns, J. (2005.), False Self. U: A. De Mijolla (ur.), International Dictionary of Psychoanalysis (str. 546-547), New York, Thomson-Gale.

Kohut, H. (1977.), The Restoration of the Self, New York: International Universities Press. 
DRUŠ. ISTRAŽ. ZAGREB GOD. 20 (2011), BR. 2 (112),

STR. $561-580$

PASKA, I.: SUVREMENO SEBSTVO..
Kohut H. i Wolf, E. S. (1978.), The Disorders of the Self and Their Outline. International Journal of Psycho-Analysis, 59: 413-425, dostupno na http://www.pep-web.org/document.php?id=ijp.059.0413a (20. 4. 2009.)

Lasch, C. (1986.), Narcistička kultura, Zagreb: ITRO Naprijed.

Magid, B. (2005.), Ordinary Mind: Exploring the Common Ground of Zen and Psychoanalysis, Boston: Wisdom Publications.

Marks-Tarlow, T. (1999.), The Self as a Dynamical System. Nonlinear Dynamics, Psychology and Life Sciences, 3 (4): 311-345. doi:10.1023/A:1021 958829905

Meronen, P. (1999.), The Return of Narcissism: Heinz Kohut in the Context of the History of the Ideas. International Forum of Psychoanalysis, 8 (3/4): 211-220. doi:10.1080/080370699300056211

Oppenheimer, A. (2005.), Fragmentation. U: A. De Mijolla (ur.), International Dictionary of Psychoanalysis (str. 605), New York, Thomson-Gale.

Palacio Espasa, F. (2005.), Anxiety. U: A. De Mijolla (ur.), International Dictionary of Psychoanalysis (str. 98-102), New York, Thomson-Gale.

Puljiz, V. (1995.), Demografski procesi i struktura obitelji (europska iskustva). Revija za socijalnu politiku, 2 (2): 123-130. doi:10.3935/rsp. v2i2.529

Riesman, D., Glazer, N. i Denny, R. (1965.), Usamljena gomila: studija o promeni američkog karaktera, Beograd: Nolit.

Schlegel, R., Hicks, A. J., Arndt, J. i King, L. A. (2009.), Thine Own Self: The True-Concept Accessibility and Meaning in Life. Journal of Personality and Social Psychology, 96 (2): 473-490. doi:10.1037/a0014060 Sennett, R. (1989.), Nestanak javnog čovjeka, Zagreb: Naprijed.

Simmel, G. (2001.), Kontrapunkti kulture (V. Katunarić, ur.), Zagreb: Naklada Jesenski i Turk, Hrvatsko sociološko društvo.

Stolorow, R. (2000.), From Isolated Minds to Experiential Worlds: An Intersubjective Space Odyssey. American Journal of Psychotherapy, 54 (2): 149-151.

Stolorow, R. D. i Atwood, G. E. (2002.), Contexts of Being: The Intersubjective Foundations of Psychological Life, New York - London: The Analytic Press.

Suesske, R. (2004.), Was meint Heinz Kohut, wenn er vom "Selbst" spricht? Psychosozial, 11 (96): 91-102

Taviss Thomson, I. (1989.), The Transformation of Social Bond: Images of Individualism in the 1920s Versus the 1970s. Social Forces, 67 (4): 851- 870. doi:10.2307/2579705

Teachman, J. D., Tedrow, L. M. i Crowder, K. D. (2000.), The Changing Demography of America's Families. Journal of Marriage and the Family, 62 (4): 1234-1246. doi:10.1111/j.1741-3737.2000.01234.x 
DRUŠ. ISTRAŽ. ZAGREB GOD. 20 (2011), BR. 2 (112)

STR. $561-580$

PASKA, I.: SUVREMENO SEBSTVO...

\section{Modern Self as Seen from the Contextual Perspective \\ Iva PASKA \\ Zagreb}

The aim of this paper is to show the embeddedness of the self in the context of its formation and existence. The paper is based on the findings of intersubjective psychoanalysis, which finds the self to be formed, and later to exist, within certain human intersubjective systems. Thus the perspectives which tend to observe the self as an isolated or transhistorical entity are problematic. Intersubjective systems are also embedded within a wider cultural system, meaning that the self is also formed and exists in a specific cultural context which influences its organization. This is shown on the case of the modern self, whose specific problems became evident in the clinical praxis of the sixties in the twentieth century. Those problems are best described by the phenomenon called "tendency towards fragmentation", observed by psychoanalyst Heinz Kohut. The phenomenon is, in this paper, linked to the context of formation and existence of the self in modern society. The general aim of this paper is thus to place modern clinical findings into a wider sociological context in a new way. Building on this perspective, the author also offers her own sociopsychoanalytic explanation of the problems of the modern self.

Keywords: self, psychoanalysis, intersubjectivity, modernity, culture

\section{Das moderne Selbst aus kontextueller Perspektive}

Iva PASKA

Zagreb

In dieser Arbeit soll auf die Verwurzelung des Selbst im Kontext seiner Gestaltung und Existenz verwiesen werden. Die Studie gründet sich auf die Erkenntnisse der intersubjektiven Psychoanalyse, der gemäß das Selbst sich formt und später innerhalb bestimmter intersubjektiver Systeme existiert. Da diese somit wiederum die Organisation des Selbst beeinflussen, ist die Betrachtung des Selbst als einer isolierten oder transhistorischen Entität problematisch. Zugleich sind intersubjektive Systeme zwangsläufig in ein breiteres Kultursystem eingebettet, und das bedeutet, dass auch das Selbst innerhalb eines spezifischen kulturellen Kontexts entsteht und existiert, durch den seine Organisation beeinflusst wird. In der vorliegenden Arbeit wird dies am 
DRUŠ. ISTRAŽ. ZAGREB GOD. 20 (2011)

BR. 2 (112)

STR. $561-580$

PASKA, I.:

SUVREMENO SEBSTVO..
Beispiel des modernen Selbst aufgezeigt, dessen spezifische Probleme zuerst in den 60er-Jahren des 20. Jahrhunderts bemerkt wurden. Als gemeinsamer Nenner eignet sich am besten die Bezeichnung "Fragmentierungstendenzen", ein erstmals von dem Psychoanalytiker Heinz Kohut beobachtetes Phänomen. Dieses Phänomen wird hier mit der Formierung und Existenz des Selbst in Zusammenhang gebracht. Das Hauptziel dieser Arbeit ist, auf innovative Weise einen Bezug zwischen zeitgenössischen klinischen Befunden und dem soziologischen Kontext der modernen Gesellschaft herzustellen. In Anlehnung an diese theoretische Perspektive unterbreitet die Verfasserin eine eigene psychoanalytische Erklärung zu Problemen, mit denen sich das zeitgenössische Selbst konfrontiert sieht.

Schlüsselbegriffe: Selbst, Psychoanalyse, Intersubjektivität, Modernität, Kultur 